DOI 10.37882/2223-2982.2021.02.37

\title{
ЛИНГВОКУЛЬТУРНЫЕ ОСОБЕННОСТИ ФРАЗЕОЛОГИЗМОВ ФРАНЦУЗСКОГО, АНГЛИЙСКОГО И РУССКОГО ЯЗЫКОВ
}

\section{LINGUOCULTURAL FEATURES OF PHRASEOLOGISMS OF FRENCH, ENGLISH AND RUSSIAN LANGUAGES}

\section{E. Sharipova \\ G. Nurpeisova \\ V. Iudashkina}

Summary: Language is a reflection of the surrounding world, in which you can always see a picture of civilization, special and distinctive for each people, ethnic group. Many ethnocultural characteristics of native speakers, peculiarities of traditions, everyday life, climatic conditions of life are reflected in the lexical groups of phraseological units. Phraseological groups preserve in themselves the way of thinking of a society of a certain era, express the worldview of an ethnic group, phobias, prejudices, traditions. The authors of the article conducted a comparative analysis of the phraseological units of the French, English and Russian languages in order to identify the semantic features in the formation of idiomatic expressions in different languages.

Keywords: language, culture, phraseological units, idiomatic expressions, ethnocultural characteristics.

\author{
Шарипова Эльвира Маннуровна \\ К.с.н., дочент, Тюменский индустриальный университет \\ elvira_sha2009@mail.ru \\ Нурпеисова Гуляйза Галиолловна \\ Ассистент, Тюменский индустриальный университет \\ lady_queen2000@mail.ru \\ Юдашкина Валентина Владимировна \\ старший преподаватель, Тюменский \\ индустриальный университет \\ brentano@yandex.ru
}

Аннотация: Язык - отражение окружающего мира, в котором всегда можно увидеть картину цивилизации, особенную и самобытную для каждого народа, этнической группы. Многие этнокультурные характеристики носителей языка, особенности традиций, быта, климатические условия жизни отражены в лексических группах фразеологизмов. Фразеологические группы консервируют в себе образ мыслей общества определённой эпохи, выражают мировоззрение этноса, фобии, предрассудки, традиции. Авторы статьи провели сравнительный анализ фразеологизмов французского, английского и русского языков с целью выявления семантических особенностей при формировании идиоматических выражений в разных языках.

Ключевые слова: язык, культура, фразеологизмы, идиоматические выражения, этнокультурные характеристики.

онного развития. В настоящее время культуру чаще отождествляют с совокупностью материальных и духовных благ, достижений прогресса человечества, представляющие определенную ценность для будущих поколений. Различие культур, в частности религиозных, может являться также и поводом для конфликтов, поскольку не всегда удается установить диалог и рациональное взаимодействие между различными культурами [1].

Язык - отражение окружающего мира, в котором всегда можно увидеть картину цивилизации, особенную и самобытную для каждого народа, этнической группы. Представитель определенного народа является носителем национального менталитета и языка. В науке язык это предмет междисциплинарного изучения, поскольку он затрагивает разные аспекты жизнедеятельности человека. Можно утверждать, что язык представляет наиболее яркую идентифицирующую характеристику этнической группы [3].

Изучение языка - это не только заучивание лексических единиц и грамматических правил, но и его социокультурных, в том числе лингвокультурных особенностей. Один из наиболее эффективных способов познания этнокультур - это анализ и исследование по- 
словиц, поговорок, национальных символов, суеверий и предрассудков, при помощи которых можно представить картину исторического, религиозного, культурного развития определенного этноса. Как правило, многие из перечисленных феноменов представлены в языке в виде устойчивых идиоматических выражений и фразеологизмов. Каждая культура специфична и анализ фразеологизмов и идиом дает понять, что интерпретация того или иного явления варьируется в зависимости от концепта, поскольку языковые приемы по-разному фиксируют детерминирование определенных понятий. Синхронный анализ идиоматических языковых единиц разных языков позволяет отметить, что суеверия и предрассудки, обычаи, различие в религиозных обрядах находит отражение во фразеологизмах. Они представляют ценный источник сведений о менталитете народа. Данные фразеологические группы консервируют в себе образ мыслей общества определённой эпохи, выражают мировоззрение этноса, фобии, предрассудки, традиции. Использование разных лингвистических приемов позволяет судить о специфике культуры.

В качестве иллюстрации вышесказанного рассмотрим идентичные фразеологизмы на трех языках: французском, английском и русском. Особенность этой группы фразеологизмов в том, что авторами представлена выборка идиом с использованием названий животных, для того чтобы сузить материал семантического кластера в рамках одной статьи. Цель данного исследования - проанализировать национально-культурный смысл фразеологических групп данных трех языков и определить различия в интерпретации трех ментальностей различных народов.

Проанализируем 8 выражений с использованием названий животных, птиц и рыб. Для удобства восприятия представим данные идиомы в следующей последовательности: русский вариант - французский вариант - дословный перевод французского варианта - английский вариант - дословный перевод английского варианта.

1. Белая ворона - Un mouton à cinq pattes - дословно: «баран на пяти ногах» - Rara avis - дословно: «редкая птица». Совпадение названия птицы в английском и русском языках, но смысл выражения понятен в дословном переводе с английского языка. Не носителю русского языка трудно понять контент прилагательного «белый» в данном выражении. Вероятно, подчеркивается нетипичный окрас данного вида птиц, которые обычно имеют черный окрас [4], [5].

2. Биться как рыба об лед - Tirer le diable par la queue - дословно: «тянуть черта за хвост» - То pull the devil by the tail - дословно: «тянуть черта за хвост». Абсолютное совпадение дословного перевода в английском и французском языках, но без использования названия животного. В данном случае определяющим было влияние суровых климатических условий российской данности. Французский и английский вариант данного выражения вероятно был основан на суевериях и вере в нечистую силу, для того чтобы выразить тщетность каких-либо усилий. При этом конструкция фразы типичная для всех трех языков - использование инфинитива [4], [5].

3. Купить кота в мешке - Acheter chat en poche - дословно: «купить кота в кармане» - To buy a pig in a poke - дословно: «купить свинью в мешке». Анализ данных выражений позволяет отметить интересный феномен: полное совпадение глаголов во всех трех языках, совпадение названия животного в русском и французском языках - «кот» и совпадение слова «карман» в английском и французском языках. Данное выражение несет смысл: купить что-то непроверенное, неизвестное. Английский вариант подчеркивает вероятность неприятного чувства при возможности увидеть покупку в последствие [4], [5].

4. Вот где собака зарыта - C'est là que gît le lièvre буквально: «вот там и зарыт заяц» - That's the heart of the matter - дословно: «вот сердце вопроса (дела)» [4], [5]. Варианты французский и русский близки по своей структуре, различие только в названии животного: собака/заяц. Английский вариант полностью отличен от двух предыдущих. Используется слово «Heart», которое зачастую является синонимов слова «Center». Например: Kremlin is the heart of Moscow.

5. Денег куры не клюют - Etre cousu d'or - буквально: «быть сшитым из золота» - Rolling in money - дословно: «кататься в деньгах». Значение фразеологизма в русском варианте объясняется Лазарем Богословским, жившем в XVI веке. В деревне, которая называлась Большие Златы, жил один зажиточный купец. Он был настолько успешен в торговле, что деньги на свой двор привозил в мешках. В очередной раз, когда его работники разгружали наполненную золотом телегу, развязалась веревка на одном мешке. Монеты рассыпались и покатились по двору. Слуги стали собирать хозяйское добро. Проходившая с полным ведром пшена дворовая девушка споткнулась и опрокинула зерно, к которому тут же сбежались куры. Жена купца, увидев это, стала кричать: «Кур гоните! Склюют наши деньги, проклятые!». Но, птицы не обращали внимания на монеты и клевали только зерно. Золото было благополучно собрано. Однако купчиха не могла успокоиться и приказала всех кур зарезать. Как не пытался её убедить муж, что все деньги собраны, женщина не верила и приказ свой не отменила. Когда домашнюю птицу порубили, расстроенный хозяин, сотрясая пустыми потрохами перед носом нераз- 
умной жены, закричал: «Ну что, видишь теперь? Денег куры не клюют!». Отсюда и происхождение данного фразеологизма [3].

6. Голодный как волк - II a une faim de loup - буквально: - «у него волчий голод» - Hungry as a hunter - дословно: «голодный как охотник» [4], [5]. Полное совпадение перевода во французском и русском языках. Английский вариант подчеркивает, что промысел охотника имеет целью добыть еды, а не является жестоким хобби.

7. Делать из мухи слона. - Faire d'une mouche d'un elephant - буквально: «делать из мухи слона» - То make a mountain out of molehill дословно: «делать гору из кротовины» [4], [5]. Снова полное совпадение французского и русского вариантов. Английский вариант далек от двух предыдущих и выглядит достаточно странным для нашего восприятия.

8. Стреляный воробей - II en a vu d'autre - буквально: «Он видел другое» - A knowing old bird - дословно: «знающая старая птица» [4], [5]. В данном случает отличие французского варианта в том, что он не является фразеологизмом, как таковым вообще. В его конструкции нет каких-либо художественных приемов, таких как метафора, эпитет, гипербола, антитеза и др., широко использующиеся во фразеологизмах.

Данная выборка, конечно, не позволяет в полной мере сделать качественный анализ фразеологизмов французского, английского и русского языков, но даже эти несколько примеров позволяют утверждать то, что многие этнокультурные характеристики носителей языка, особенности традиций, быта, климатические условия жизни отражены в лексических группах фразеологизмов. Несомненно, было бы интересно исследовать и проанализировать фразеологизмы французского, английского и русского языков с фразеологическими оборотами восточных и арабских языков. Априори можно предположить, что их разногласия были бы гораздо существеннее в силу различия этнокультурных особенностей этих цивилизаций.

\section{ЛИТЕРАТУРА}

1. Маслова В.А. Homo lingualis в культуре. - Москва: Гнозис, 2007. 320 с.

2. Ожегов С.А., Шведова Н.Ю. Толковый словарь русского языка 80000 слов и фразеологических выражений/ Российская академия наук. Институт русского языка им. В.В. Виноградова. - 4-е издание дополненное. Москва.: Азбуковник, 1997. 944 с.

3. Происхождение и значение фразеологизма [Электронный ресурс] URL: https://fb.ru/article/281279/proishojdenie-i-znachenie-frazeologizma-kuryi-neklyuyut (дата обращения: 29.09.2020).

4. Французские фразеологизмы [Электронный ресурс] - URL: http://imadin12.narod.ru/french/les_idiomes.html (дата 0бращения: 29.09.2020).

5. Идиомы в английском языке [Электронный ресурс] - URL: https://puzzle-english.com/directory/idioms (дата обращения: 29.09.2020).

( Ш Шарипова Эльвира Маннуровна (elvira_sha2009@mail.ru), Нурпеисова Гуляйза Галиолловна (lady_queen2000@mail.ru ), Юдашкина Валентина Владимировна (brentano@yandex.ru ).

Журнал «Современная наука: актуальные проблемы теории и практики» 